European journal of American studies

\title{
Horsing Around: Carnivalesque Humor and the Aesthetics of Dehierarchization in Mister Ed
}

Stefan L. Brandt

\section{(2) OpenEdition}

\section{Journals}

Electronic version

URL: https://journals.openedition.org/ejas/12474

DOI: 10.4000 /ejas. 12474

ISSN: 1991-9336

Publisher

European Association for American Studies

\section{Electronic reference}

Stefan L. Brandt, "Horsing Around: Carnivalesque Humor and the Aesthetics of Dehierarchization in Mister Ed", European journal of American studies [Online], 13-1 | 2018, Online since 26 June 2018, connection on 08 July 2021. URL: http://journals.openedition.org/ejas/12474 ; DOI: https://doi.org/ 10.4000/ejas. 12474

This text was automatically generated on 8 July 2021.

Creative Commons License 


\title{
Horsing Around: Carnivalesque Humor and the Aesthetics of Dehierarchization in Mister $E d^{1}$
}

\author{
Stefan L. Brandt
}

\section{The Sitcom Genre and Carnivalesque Humor}

1 "An animal sits at a desk, writing"-thus Philip Armstrong begins his study of the meaning of animals in fictions of modernity (What Animals Mean 1). The scenario of an animal writing a letter while sitting at a desk may seem absurd; yet, this is the exact setting that viewers of the TV sitcom Mister Ed are confronted with in the 1962 episode "Horse Sense" (season 3, episode 6): The show's animal protagonist, a white palomino horse named Mister Ed, stands at a desk and produces a letter on a typewriter (Fig. 1). ${ }^{2}$ By acting like (but not necessarily as) a human, Mister Ed embodies ethnologist Claude Lévi-Strauss's famous dictum that natural species are "good to think with" (89). In cultural practice, animals thus function as symbols, epitomizing ideas such as equality, liberty, and justice. According to Lévi-Strauss, animal characters teach us what the tenets and limits of our culture are and how they are fashioned. Such fictionalized-and often anthropomorphized-animals may thus figure as "stand-ins for humans," as Margo DeMello has put it (334). ${ }^{3}$ Their prime function is to represent human concerns and sensitivities, not those of animals. What is true for literature and cinema is perhaps even more applicable to television-a medium which aspires to connect to our imagination in a place where we are most susceptible to aesthetically encapsulated messages: our own homes. Tellingly, U.S. television in the 1950s was teeming with dogs and horses-a vague echo of their popularity in various films since the 1920 s. $^{4}$ Touching upon socially explosive topics such as authority and independence, animal representations in the 1950s shied away from being overtly political, however. This situation changed significantly in the 1960s. ${ }^{5}$ 




Fig. 1: Mister Ed typing a letter in the episode "Horse Sense" (1962). Screenshot taken from the Mister Ed: The Complete Series DVD distributed by Shout!Factory.

2 As I will postulate in this essay, the sitcom Mister Ed, which ran on CBS from 1961 to 1966, offers some of the most daring, yet carefully packaged, political statements in sixties animal television. The titular horse lives with his eccentric owner Wilbur Post, a likeable daydreamer and architect, and his accepting wife Carol. Mister Ed's home in the San Fernando Valley, California, is a stable, which, however, more resembles a residence, furnished with a TV set and a typewriter. Ed is not only intelligent, but has the ability to talk-a skill that he only demonstrates in the proximity of his owner Wilbur. One of the show's running gags is that Ed immediately becomes silent when other people join him and Wilbur (which leads to a couple of comical situations in which Ed's owner is seemingly talking to himself, often being mistaken for a mentallyill person).

Despite its rather atypical subject matter, Mister Ed became one of CBS's most popular shows in the early sixties. ${ }^{6}$ The original title for the project (when it was first developed in 1958) was The Wonderful World of Wilbur Pope, indicating the show's initial focus on the owner, Wilbur Pope (later changed to Wilbur Post and in the original played by Scott McKay), rather than the horse (Terrace 151). The eventual shift of focus from Wilbur to Mister Ed renders possible the show's thematic emphasis on the world of animals (and on its equine protagonist, in particular), implying an increased awareness of marginalized figures. ${ }^{7}$

4 More so than its preceding formats, Mister Ed assumed a politically informed stance, weaving the social concerns of the turbulent sixties into the realm of mass entertainment. In my reading, the show deliberately employs the aesthetics of popular culture in order to formulate its subversive criticism of American culture (and the representation of minorities, in particular). ${ }^{8}$ Following Terry Eagleton, I define "aesthetics" as a set of sensory interactions between the world and the body that 
reflect "the whole of our sensate life together" (13). Similar to art itself, aesthetics figures as a historically shaped array of cultural discourses, permeated by ideologies. It is precisely this political dimension of aesthetics that I will discuss in this essay. Popular culture is tied to the realm of aesthetics in a unique way, since it necessitates specific modes of targeting large audiences (see Shusterman 289-307). Aesthetic pleasure cuts across the lines between "high art" and "popular art," finding its own idiosyncratic expression in the ephemeral nature of modern-day culture. "[M]ost pleasures of beauty, art, and entertainment," Richard Shusterman has argued, "are not only valuable without being everlasting but are more valuable because they are not" (307). These observations enable us to link aesthetic pleasure to the dynamics of popular culture, and to the sitcom, with its seemingly volatile, jocular rhythm, in particular.

5 The genre of the sitcom plays an important role in the cultural practice of comedic subversion. ${ }^{9}$ Marked by its "television-ness," the sitcom makes use of the generic aspects of mass entertainment to reach its audiences (Mills, Sitcom 13). The sitcom employs a set of carefully elaborated aesthetic patterns to develop its unique type of humor, often subverting ideologies and prompting audiences to think about the nature of the represented acts. In this sense, the genre makes use of the potential of aesthetic acts to subvert established narrative patterns and to emphasize counter-hegemonic forms of cultural practice, thereby articulating social criticism (see Eagleton 118-119). As a genre, the sitcom became "mass-compatible" during the 1950s, connecting itself to a kind of "hysterical" humor which, according to Ed Sikov, dominated during the postwar era. "10 "Comedy, as a stimulus to laugh," John A. Fisher states in his contribution to The Routledge Companion to Aesthetics, "has always been cast into the realm of the lower art" (530). Popular culture, Fisher explains, often recurs to formulaic patterns of representation, offering audiences mass-produced items in the form of commercial feature films and television productions $(533 ; 535){ }^{11}$

The sitcom genre is a prime example of this "formulaic" reconstruction of reality (see Mills, Sitcom 43). Sitcoms, John Mundy and Glyn White have explained, are usually "designed around a star, a double act or team, or have a carefully constructed ensemble cast" (106).$^{12}$ In the case of Mister Ed, the main focus undoubtedly lies upon its title character Mister Ed-not a human performer, but a horse who functions as the show's key focalizer. Notably, Ed introduces himself to audiences at the beginning of each episode ("Hello .... I'm Mister Ed" 00:03-00:07). By turning a horse into the star of the show, Mister $E d$ simultaneously uses the formulaic strategy of many sitcoms (revolving around one particular performer) and subverts it (by making the talking horse the main focalizer and, in some cases, even the narrator of the show). ${ }^{13}$ According to Brett Mills, "the sitcom's artificiality marks it off as different to the majority of the medium's fiction" (Television Sitcom 75). In Mister Ed, this "artificiality" is enhanced by the unrealistic-and physically impossible-perspective of a talking horse. Through this absurd narrative device, the show enables viewers to imagine situations marked by a disruption of hierarchies and power structures. This constellation calls to mind Mikhail Bakhtin's theory of "[c]arnivalesque humor" (Rabelais 15). According to Bakhtin, this type of dehierarchizing humor generates a subversive effect upon audiences by valorizing grotesque characters and settings. In its celebration of the absurd and ludicrous, the "carnivalesque consciousness" (Rabelais 275) lets us share the viewpoints of characters which are otherwise usually placed on the periphery of society. ${ }^{14}$ 
7 In the following, I will discuss the marginalized animal, which Mister Ed accentuates, in three interrelated steps: First, I will examine the idea of the "animal subaltern" and its significance for the sitcom Mister Ed. This section will demonstrate that the protagonist's actions and utterances showcase his agency. Second, I will explore the concept of "bestial ambivalence" and its relation to Mister Ed's shapeshifting persona. This section will suggest that Mister Ed constantly oscillates between different subject positions designed to familiarize viewers with a wide spectrum of identity options and ridicule established conventions of Western thinking. Third, I will turn to the political dimensions of the show by drawing on the notion of "animal denizenship." This concept will allow for a dissection of the boundaries between the human and the nonhuman. Rather than trying to convince audiences that Mister Ed is a real horse, Mister $E d$ plays with the fiction of what Philip Armstrong has called "non-human agency" (Animals 3). ${ }^{15}$ Thus, the series uses an aesthetics of dehierarchization in order to encourage audiences to question existing categories and experiential modes of connecting to minority subjectivities.

\section{Rendering the "Impossible" Possible: Postcolonial Theory and the Animal Subaltern}

8 In Mister Ed, the eponymous character becomes (politically) empowered in a double sense: Not only does the show humorously promote the political agenda of the burgeoning Civil Rights movement (for example, by turning its title character into a "beatnik" and amiable spokesperson of the "disfranchised"), it also toys with the idea that animals may possess a form of agency that could go beyond their mere ability to "suffer" (Derrida 28). In Mister Ed, the animal's "vulnerability," characterized by Jacques Derrida as the core of its ultimate inability and powerlessness in the face of human domination, transforms into a grotesquely empowering and dehierarchizing force. Since conventional power structures are repeatedly turned on their head in the show's comical universe, audiences gain the impression that animals do, indeed, possess the potential for disruption and rebellion-even though this illusion is formulaically destroyed at the end of each episode. Ed's continual suffering in the face of injustice (including his symbolic fight against this unfair system) is a case in point for the condition of animals in human society that Derrida has called "a possibility without power, a possibility of the impossible" (28). In the world of the show, Mister Ed, the anarchist horse, overcomes the phase of suffering and gradually begins to change his environment. By using subversive strategies, the show visualizes hidden aspects of a potential reality that seems, in Michel Foucault's terms, "impossible to think" (Order $\mathrm{xv}$ ), such as the notion that a horse could develop its own horizon of perception and figure as an independent agent of events. ${ }^{16}$ Referring to Donna Haraway's seminal observations in her essays "Situated Knowledges" (1988) and "The Biopolitics of Postmodern Bodies" (1989), Philip Armstrong offers the following comments on the issue of animal agency: "The possibility of treating non-humans as something other than passive objects of study was anticipated in a paper by Donna Haraway that espoused the recognition of the non-human world as a 'witty agent and actor,' a 'coding trickster, an active collaborator in the construction of meaning, or a rebellious obstacle to it" (Animals 2). 
9 By imaginatively suggesting that animal agency is, in fact, possible, Mister Ed toys with ontological questions posed by the discipline of animal studies, especially regarding the dogma of anthropocentrism. Whereas anthropocentrism assumes that humankind is "the central or most important element of existence" ("Anthropocentric"), Mister Ed enquires into the nature of anthropocentrism, asking questions such as: What distinguishes the human species from the species of animals? ${ }^{17}$ What happens to these boundaries once the "animal subaltern" begins to speak? These questions point to the usefulness of postcolonial studies for analyses of animal representations. Various academic studies have suggested that there are, indeed, parallels between the position of the oppressed in colonial imperialist systems and that of non-human species in a world dominated by humans (see, for example, Ahuja; Armstrong; Chagani; Moore; Willett). Conceived in this manner, animals are placed in the position of the "subaltern," deprived of a sense of agency. Some authors have stepped beyond the discipline of postcolonial animal studies, pointing to a need for what Graham Huggan and Helen Tiffin call "postcolonial ecocriticism" in their book by the same title. "Postcolonial ecocriticism," the authors propose, combines the theoretical interests of aesthetics and the political goals of animal advocacy, thus "preserv[ing] the aesthetic function of the literary text while drawing attention to its social and political usefulness, its capacity to set out symbolic guidelines for the material transformation of the world" (14)..$^{18}$

In his influential essay "The Postcolonial Animal" (2002), Philip Armstrong points to the opportunity that postcolonial theory offers for better understanding animals as existentially independent agents: "Encountering the postcolonial animal means learning to listen to the voices of all kinds of 'other' without either ventriloquizing them or assigning to them accents so foreign that they never can be understood" (7). Neel Ahuja, in his "Postcolonial Critique in a Multispecies World" (2009), praises the potential of "species studies" as a discipline that "offers new tools for rethinking transnational circuits of power and identity" (556). Following Ahuja, "species studies" allows us to shed new light on the position of minorities within a larger imperialist discourse, which necessarily involves the treatment of non-humans: "By tracing the circulation of nonhuman species as both figures and materialized bodies within the circuits of imperial biopower, species critique helps scholars reevaluate 'minority' discourses and enrich histories of imperial encounters" (556-557).

11 Indeed, the sitcom Mister Ed revolves around a "minority discourse"-that of the animal other, epitomized by the "figure" and the "materialized body" of the horse protagonist. Not only does Mister Ed take the proverbial spotlight in all 143 episodes, the character also "materializes" as a real horse (and not just a figment of Wilbur's imagination). Mister Ed's disenfranchisement as a citizen is taken literally in the 1961 episode "Ed the Voter," in which the show's title character demands his right to vote. Ed's democratic fervor is underlined in one of the episode's first scenes, where he exclaims, "If a horse ever runs for president, I'll make a speech" (1:29-1:33). When it turns out that it is harder than Ed thought to exercise his right to vote, Ed resigns in frustration, telling Wilbur and viewers, "I still wish I could vote" (23:26-23:28). ${ }^{19}$ In view of the show's (humorous) accentuation of Ed's exclusion from elections, one could easily argue that the main character figures as what Cynthia Willett has called "the animal subaltern" (26). ${ }^{20}$ 
12 The sitcom's humor plays a decisive role in establishing Ed as a likeable character, whose concerns regarding his right to vote we fully understand. Laughing with Ed about the pitfalls of bureaucracy and the inertia of democracy enables a valorization of the subaltern through the show's microstructure. "Subaltern studies," Cynthia Willett reminds us, "have established that ridicule and other forms of humor serve not only as accessories of cruelty and props of power but also provide discourses and technologies of reversal, leveling hierarchies by turning stratified structures upside down" (30; my emphasis). These observations lead Willett to the rhetorical question: "Can the animal subaltern laugh?" (29). Analogously, Fayaz Chagani, in a more recent essay, asks: "Can the Postcolonial Animal Speak?" (619). Mister Ed, I contend, literally lets "the subaltern speak" (2117), to cite the metaphor from Spivak's original essay (1988). ${ }^{21}$ One of the first theorists of what later came to be known as postcolonial studies, Frantz Fanon, already pointed to the analogies between the "colonized" and the "animal" in the rhetoric of colonialism-a rhetoric which can be countered by the colonized with "roaring laughter": "When the colonist speaks of the colonized he uses zoological terms .... The colonized know all that and roar with laughter every time they hear themselves called an animal by the other. For they know that they are not animals. And at the very moment when they discover their humanity, they begin to sharpen their weapons to secure its victory" (7-8).

13 In Mister Ed, the title character is empowered through this laughter. In numerous episodes, Ed "sharpens his weapons," to take up Fanon's metaphor, in order to rebel against the human system of oppression. Mister Ed has the viewers on his side through the use of ridicule and laughter, which are generally directed against the world of humans. Here, the sitcom uses the strategies of comedic reversal and grotesque distortion to advocate minority issues. In placing the marginalized character of a horse at the narrative center and endowing it with a powerful subject position (manifested through the force of laughter), Mister Ed turns an impossibility into a possibility. The show playfully challenges our assumptions regarding the "nature" and "function" of human and non-human species in society, enabling us to re-imagine marginalized identities and associate ourselves with the liminality of such positions.

\section{Horseplay: "Bestial Ambivalence" and the Aesthetics of Shapeshifting}

14 In this grotesque play with hierarchies, Mister Ed figures as the epitome of what Paul Wells has termed "bestial ambivalence" (51), which denotes a radical shifting between oppositional representations of body, identity, gender, race, ethnicity, and species. Instead of confronting us with a static image of animal-ness, key texts in Western culture (such as Disney's 1967 film The Jungle Book) toy with a "set of oscillations" which portrays animal (and to a certain extent human characters, as well) in a "representational flux" (Wells 51), vacillating between intermediate stages of "animal" and "human." Wells argues that these texts reveal a kind of "discourse-in-flux" that represents "animal-in-the-making" (125; my emphasis) rather than the presumably "essential" entities of either human or animal. Following Wells's notion of "bestial ambivalence," Mister Ed figures neither as "pure animal" nor as merely a "human in animal disguise." In fact, Ed's owner Wilbur acknowledges this "bestial ambivalence" when he quips, "I just expect you to act like an... uhmm... normal human horse" ("Ed 
the Beachcomber" 14:07-14:08). Constantly ridiculing the other (human) characters with his wisecracks, Mister Ed is the epitome of the young rebel who mocks social norms and values, thereby often questioning the boundaries between animals and humans. As such, Mister Ed is more than simply a "stand-in for humans," to pick up DeMello's phrase, but actually replaces-by means of his "bestial ambivalence"-human characters as the focal point, creating narrative space for concerns which go far beyond the realm of human interaction. To use Haraway's terminology, Mister Ed functions as both a "witty agent and actor" (209) and a "coding trickster" (201), who is all but passive in the choice of his actions.

15 Likewise, throughout the series, Mister Ed is characterized as a constant shapeshifter: grumpy, cynical, naïve, but also kind and loving. As part of this strategy of shapeshifting, Ed is also associated with an archetypal Hollywood character-the lonesome western hero. Equipped with the sonorous voice of a cowboy (which, incidentally, was that of former cowboy actor Allan "Rocky" Lane), Mister Ed reflects the values of individualism and non-conformism cultivated in American western films, but from the perspective of a horse. "I'm a westerner myself," Ed declares in one episode, "I was born under the saddle" ("Ed the Desert Rat" 01:36-01:40). ${ }^{22}$ The show's key joke is that a horse performs the role of the western hero-the animal which, in the western formula, functions as a vehicle, not as an agent of events. Here, the classic formula of westerns is humorously reversed, turning the horse into the narrative center of the plot. While, in the typical western, horses are no more than mere background props, Mister Ed is very much at the center of our attention and the focalizer of all narrated events. The tongue-in-cheek dimension of Ed's transformation into a "westerner" becomes even more obvious in the ensuing scene from "Ed the Desert Rat" (1964; season 4, episode 17), in which Ed performs the role of a western loner, with a cowboy hat on his head. "You know what we ought to do someday, Wilbur?" he addresses his owner, "We ought to get out in the wide open spaces ... and rough it. The sky for our roof and the ground for our bed" (01:45-01:57). In the ironic reversal of the show, the horse, not the rider, serves as the admired hero. "I belong out in the wide open spaces," Ed affirms in the same episode (02:17-02:19), jokingly putting himself in the position of the western hero and his owner in the domesticated, passive role.

16 The symbolic reversal between "horse" and "rider" likewise appears in the 1963 episode "Ed Discovers America" (season 4, episode 3), in which Ed's owner Wilbur is commissioned to design a museum. Looking for an idea about which statue to place in front of the building-"something that symbolizes the spirit of America" (02:35-02:38) -he turns to Mister Ed. The ensuing conversation reveals fundamental differences as to whom this statue should depict. "Aaah, something that symbolizes the spirit of America, huh?" (02:40-02:43), Ed repeats. While Wilbur makes various suggestions ("a statue of the American Indian," "the pilgrim," and "Washington in a rowboat"), Ed keeps repeating monotonously, "What about a horse?" (02:45-03:03). Even after Wilbur rejects the idea, Ed insists: "There's gonna be a statue of a horse in front of that building" (03:32-03:35). The "argument" brought forth by Mister Ed-that horses represent the American spirit of westward movement-must have rung true to many television consumers. As countless movies and TV shows of the postwar era conveyed, horses did indeed accompany the treks of settlers into the Wild West and across the frontier (see Ahmad). The show exploits its conscious reversal of roles-between 
human and animal, pioneer and horse-to declare the horse the crucial agent of American progress, doing the job even better than its human counterpart. "Never send a man to do a horse's job," Mister Ed quips in the episode "Ed the Desert Rat" (07:2407:27). Horses, the plotline suggests, are simply more competent and more in tune with the American spirit than humans. The horse protagonist of Mister Ed thus figures, in a Bakhtinian sense, as a "carnivalesque" character. By laughing with Mister Ed (rather than about him), we partly identify with his outsider status and begin to understand the ramifications of his "otherness" within human society. "23 "Carnival laughter," Bakhtin explains in Rabelais and His World (1965), "is the laughter of all people. ... [I]t is directed at all and everyone, including the carnival's participants. The entire world is seen in its droll aspect, in its gay relativity" (11). The dehierarchizing potential of carnival laughter becomes obvious in "Ed the Voter" (1961; season 2, episode 6), in which Ed is asked what he would change if he was elected U.S. President. "For one thing," he answers, "horses would be riding people" (23:41-23:44). Ed's second plan seems equally emancipatory for the world of horses: "Every time a horse won a race, the winnings would be put aside for his old age" (23:47-23:52). Mister Ed's "carnivalesque" humor here accentuates the ambivalent and liberating dimensions of its aesthetics: We may laugh about the very fact that a horse is talking and making jokes at the expense of its owner; at the same time, we laugh about the world of humans which, to use Bakhtin's phrase, is shown "in its droll aspect."

The laughter evoked by Mister Ed is "ambivalent: it is gay, triumphant, and at the same time mocking, deriding. It asserts and denies, it buries and revives" (Bakhtin, Rabelais 11-12). The comedic emphasis on the formulaic in Mister Ed thus generates a spectacle that may be called "a syncretic pageantry of a ritualistic sort" (Bakhtin, Dostoevsky's Poetics 22; original italics). In this type of pageantry, Mister Ed's protagonist functions as a "grotesque character" (Bakhtin, Rabelais 316), flagrantly oscillating between the world of humans and that of animals. Thus conceived, the show puts forward a narrative in which the human/non-human relationship gradually tilts in a carnivalesque fashion, generating new angles with regard to the issue of animal agency. Notably, the illusion of seeing a horse talk is evoked by a trick designed by the makers of the show: While the rest of Mister Ed's body usually remains still (or barely changes its position), the horse's mouth is constantly moving during Ed's monologues. ${ }^{24}$ As Bakhtin observes with regard to the carnivalesque performance, "the most important of all ... features for the grotesque is the mouth. It dominates all else" (Rabelais 317). Mister Ed's formula is so absurd and fantastic (showing the protagonist in the role of a cowboy, writer, politician, and so on) that it creates an imagery of empowerment on the part of the animal figure in the audience's imagination. ${ }^{25}$

Throughout all six seasons of Mister Ed, Thomas Paine's 1776 treatise Common Sense, a highly influential founding document of the United States, is used as a point of reference. However, in the show, not "common sense," but "horse sense" moves the action forward. In an episode titled "Horse Sense" (1962; season 3, episode 6), Mister Ed writes a newspaper article and later even a book that Wilbur sells as the product of his own efforts. When the fraud is revealed, Ed dryly remarks: "Looks like my brain has gone to his head" (15:38). This episode highlights that Mister Ed does not only revolve around its animal character in plot and dramaturgy (this would be a criterion fulfilled by many 1960s programs such as Lassie, which ran on CBS from 1954 to 1971); rather, it rejects the predominant anthropocentric agenda of other shows, making its protagonist the center of the show's sentient universe and sharing the character's 
interior values and perceptions. ${ }^{26}$ This departure from television's dogmatic anthropocentric conventions is illustrated in another Mister Ed episode, aptly titled "Ed Finally Talks" (aired on February 18, 1962), which, once again, employs the show's key motif of "horse sense." In a comedic dream sequence (Fig. 2), Ed not only receives a university degree but also becomes an army major and even a member of the U.S. Senate, where he gives a passionate speech on the topic of common sense: "Fellow congressmen, we're getting nowhere with people sense. It's time now for a little horse sense" (20:59-21:50). In this episode, Mister Ed is equipped with a strong, rebellious voice. He speaks up to his owner-“Get lost, boy, I'm introducing a new bill" (21:3721:39)-and is repeatedly awarded for his irreverence. "Animal sense" and "people sense" are thus humorously juxtaposed. Through its tongue-in-cheek humor, the show makes it clear which one the audience is expected to favor. The notion of "horse sense" toys with an idea heralded by Spivak in her Foucauldian critique of postcolonial reason, namely that "the subtext of the palimpsestic narrative of imperialism be recognized as 'subjugated knowledge,' 'a whole set of knowledges that have been disqualified as inadequate to their task or insufficiently elaborated"' (2115).

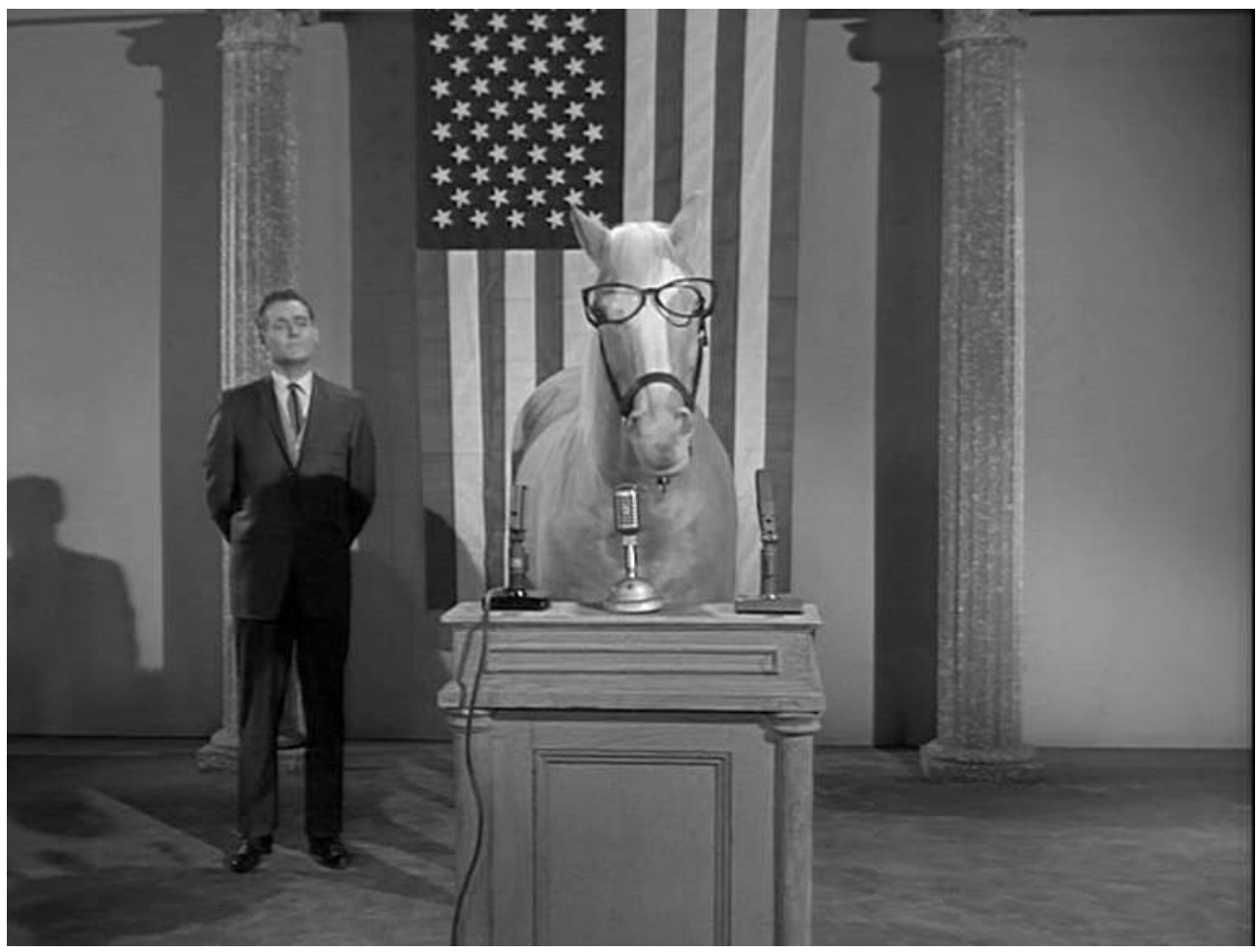

Fig. 2: Mister Ed giving a speech in Congress in the episode "Ed Finally Talks" (1962). Screenshot taken from the Mister Ed: The Complete Series DVD distributed by Shout!Factory.

In Mister Ed, this subjugated knowledge is attributed to animals, which are, indeed, "located low down on the hierarchy, beneath the required level of cognition or scientificity," to use Foucault's terminology (Power/Knowledge 82). ${ }^{27}$ Mister Ed is "knowledgeable" in a literal sense: He does not only have profound insights into the world of animals, but is also sophisticated and eloquent when it comes to human cultural practices. He writes brilliant essays, outwits each character with his jokes (including his owner Wilbur), and has read the classics of American literature such as Henry Wadsworth Longfellow and James Fenimore Cooper, as clarified in "Ed the Voter" (24:21-24:34). In the episode "Ed the Beachcomber" (1962; season 2, episode 23), Ed recites witty odes that he performs as "Henry Horseworth Longfellow" (14:09-14:29). 
Mister Ed may be smarter than all those around him; yet, with the exception of his owner Wilbur, no one knows about the horse's extraordinary intellectual capabilities. However, by exhibiting his talents to Wilbur and the viewers of the show, the character steps out of the "Self's shadow" (Spivak 2114) and develops his own unique Self, which is a carnivalesque compound of human and animal. Resisting his position as "the Other," Mister Ed recreates his "subjugated knowledge" as what the show calls "horse sense." Modeled after Paine's "Common Sense," this comical concept valorizes the fundamental rights of animals as sentient creatures that deserve equal treatment. In Picturing the Beast (1993), Steve Baker argues that "our ideas of the animal ... are the ones which enable us to frame and express ideas about human identity" (6; original italics). Mister $E d$ negotiates these ideas as pertaining to the fundamental rights that every individual in society should enjoy, no matter to which species they belong. The show thus offers a subtle denouncement of what Peter Singer has described as "speciesism" (Animal Liberation 185), humans' irrational and unjust discrimination against animals, and, more particularly, different types of discrimination against different types of animals-friends or food.

In this context, it is highly suggestive that Mister Ed is not just any animal, but a horse. Horses are not only connected to the American westward movement, but also to a sense of injustice and suffering in general. As early as 1828 , the philosopher Jeremy Bentham remarked that "a full-grown horse ... is beyond comparison a more rational ... animal than an infant" (qtd. in Garrard 147). Bentham went on to explain that the decisive question concerning non-human subjectivity is not if animals can think but if they can suffer (Garrard 147). More than other animals, horses have a history of being abused as effective tools of the economic system. According to Harold F. Hintz, horses are marked in our culture as both powerful and easily tamable $(12-13 ; 117)$. For hundreds of years, horses had to serve as tools of transport and labor power. ${ }^{28}$ In $1890,70 \%$ of urban traffic in the USA depended on horse-drawn tram. In light of these horrors, it is no wonder that J.D. Salinger's youthful hero in The Catcher in the Rye (1951) exclaims: "A horse is at least human, for God's sake" (117; original italics). This paradoxical message from Salinger's bildungsroman-that horses are, in a way, also "human"-which permeates almost every episode of Mister Ed.

\section{Pushing the Boundaries of Human and Non-Human: Mister Ed as a "Liminal Animal Denizen"}

21 Through the show's liminal aesthetics, Mister Ed endorses what Sue Donaldson and Will Kymlicka have termed "[1]iminal animal denizenship" (244)-a type of identity position that situates the non-human in the space between domestication and independence (but with certain additional and inalienable rights that a wild animal would not be granted). As Donaldson and Kymlicka explain in their book chapter on "Liminal Animal Denizens," this type of animal is marked by both confinement and a relative sense of freedom. "Liminal animal denizens" enjoy protection and security within the civilized home, yet they never become fully "domesticated companions of humans" (241). ${ }^{29}$ Mister Ed, too, belongs to this group of threshold animals "who live amongst us, even in the heart of the city" (210). The show suggests that Ed stays with Wilbur of his own volition-simply because he appreciates him as a friend and soulmate. In this sense, he is a resident of two worlds, that of humans and that of animals, partly domesticated, 
yet also partly autonomous. Donaldson and Kymlicka "call this group liminal animals, to indicate their in-between status, neither wilderness animals nor domesticated animals. Sometimes they live amongst us because humans have encroached on or encircled their traditional habitat, leaving them no choice but to adapt as best as they can to human settlement" (210; my emphasis).

A chief characteristic of "liminal animals" is that "these animals are invisible in our everyday worldview" (211). In a similar fashion, Mister Ed, too, is "invisible" to his diegetic observers, except to his owner Wilbur and to the viewers. The other characters in the show can see the physical appearance of a horse but are unable to see Mister Ed as Wilbur and audiences perceive him-as a witty, wisecracking genius who is more intelligent than anyone in his environment. In this sense, the position of Mister Ed as a "liminal animal" is "highly paradoxical" (211). After all, Ed carries all the traits that would normally qualify him as a "person" and full member of society (including voting and property rights), yet he is not given these privileges, since society does not recognize his fundamental status as a citizen. "Liminal animals," Donaldson and Kymlicka state, "are not domesticated, and so do not trust humans, and typically avoid direct contact" (214). Mister Ed, too, avoids contact with humans. The only human he ever trusts enough to engage in conversation is his owner Wilbur Post. The special privileges that Ed enjoys, thanks to Wilbur, include a bed, a telephone, a typewriter, and the right to be heard in problematic situations. This enhanced status as a coresident is comparable to what Donaldson and Kymlicka define as "denizenship":

Denizenship captures this distinctive status, which is fundamentally different from either co-citizenship or external sovereignty. Like citizenship, denizenship is a relationship that should be governed by norms of justice, but it is a looser sort of relationship, less intimate or cooperative, and therefore characterized by a reduced set of rights and responsibilities. (214)

This "reduced set of rights and responsibilities" includes two components that Donaldson and Kymlicka isolate as key markers of "liminal animal denizenship": (a) "[s]ecure residency" and (b) "[f]air terms of reciprocity" (241; original italics). Ed enjoys both of these privileges. His denizen position in the Post residence is not endangered (although Ed repeatedly breaks out of his home). In addition, the relationship between Ed and Wilbur is based on mutual trust, exchange, and interdependence. Here, the liminal dimension of Mister Ed becomes obvious. While recognizably a horse (indeed, one that is proud of its species in its own right and never shows any aspirations to become a human), Wilbur, nevertheless, treats Mister Ed as a human, who is a responsible and equal partner in the home. Ed's "humanity" (in the philosophical sense) becomes visible in the character's constant resistance to acts of injustice and his generally contrarian attitude toward his environment. When asked, in the 1961 episode "Ed Agrees to Talk" (season 1, episode 20), if he has been eavesdropping, Mister Ed has a snappy answer: "Yes and no. Yes if you saw me, and no if you didn't" (01:30-01:32). Ed's disobedient reactions throughout the show indicate the sense of empowerment he feels toward his owner, which may result in gratification on the part of the viewer (Shillinglaw 248). Time and again, the horse proves to be unruly and non-conformist, rejecting traditional norms and challenging expectations.

As Ann Shillinglaw observes, Mister Ed is marked as a prototypical boundary crosser that "transgresses space, action, realism, and logic, moving into living rooms, neighbors' homes, the desert, lines at the bank .... Ed is barrierless, even fitting into physically impossible spaces such as the cockpit of an airplane" (248). In this regard, 
Mister Ed is a kind of alter ego of his human counterpart, articulating desires that Wilbur does not dare to express, let alone turn into actions. Mister Ed becomes, as the administrator of the internet blog HorsesforDiscourses has put it, a kind of "Mister Id." $\mathrm{He}$ is the substantiation of Wilbur's repressed and perhaps forgotten wish to trespass the boundaries of social norms. Mister Ed dares what Wilbur dares not. If Wilbur is characterized as rather shy and restrained, Mister Ed proves bold and confident. Yet, Ed is never fully marked as either horse or human, but rather inhabits a liminal space "in between" these two subject positions.

This sense of liminal subjectivity on Ed's part is illustrated in the episode "Ed the Beachcomber," in which Mister Ed joins a number of beatniks that Wilbur's oldfashioned neighbor Addison aspires to expel from his private beach property. Ed's solidarity with the beatniks is motivated by the fact that he also feels alienated from his environment. In a key scene, Ed transfers the sentiment of the beatnik outsider melodramatically-and comically-to his own species: "There's no place for us horses today" (12:25-12:28). Using almost exactly the same words previously articulated by the rebellious juveniles, Ed exclaims: "We're rejected, neglected, befuddled, bemuddled" (12:29-12:36)..$^{30}$ Ed's anguish in the face of his subjugated status in society evokes Bentham's question "Can they suffer?" which, for Derrida, highlights "the unprecedented proportions of this subjection of the animal" (25; original italics).

As Derrida explains, "[b]eing able to suffer is no longer a power; it is a possibility without power, a possibility of the impossible" (28). While reminding its audiences that Ed's rebellious performances are in vain and doomed to failure toward the end of each episode, the show nevertheless stages them as understandable and ultimately necessary acts that merit admiration and perhaps even emulation. Thus, we actually see Ed celebrating with the beatniks and enjoying some sense of emancipation. Mister Ed's temporary breaking free of social bonds is an act that his civilized owner Wilbur would likely never allow himself to perform. Yet, we assume that he would very much like to, since he, too, is treated as an outsider by society. Repeatedly, his wife and neighbors ask him to see a shrink, since they do not believe his assertion that Ed actually speaks. "[T]he similarity between the name Ed and the word 'id," Shillinglaw notes, "cannot be unintentional in a show which, in a variety of episodes, presents Wilbur consulting with psychologists" (251).

As his owner's alter ego, Mister Ed fulfills the hidden dreams and fantasies that Wilbur cannot realize due to the omnipresent constraints of society. This is where the "possibility of the impossible" Derrida assigns to animals is turned into a reality, after all. While the human character is unable to transgress boundaries and go beyond the assigned sphere, paradoxically enough, the horse Mister Ed is allowed to control airplanes, give speeches to Congress, and so on. This reversal of roles between humans and animals is illustrated in a hilarious plot twist in the episode "Ed Finally Talks," where we see both human and animal trying to study the mind of the other. While Wilbur reads a book on animal psychology, Ed peruses a scholarly study on human psychology. In asserting that "animals are smarter than humans" (07:56-07:59), Ed mockingly reverses the cliché that humans are more rational. Mister Ed's actions continuously highlight the actual agency of his species and reject the arrogance of humans. In this regard, I disagree with Ann Shillinglaw who, in her article "Mister Ed Was a Sexist Pig," holds that Ed's actions are mainly motivated by misogyny. Ed's disparaging attitude toward his environment is not just directed toward women, but 
humans in general. In fact, the character is marked by a strong sense of misanthropy. Wilbur is the only human character with whom Mister Ed speaks. For most other human characters-perhaps with the exception of one-time guest star Mae West-Ed has nothing but contempt. In the comic universe of the show, Mister Ed's misanthropic attitude makes perfect sense. After all, it is the humans who deny Mister Ed-and other animals-basic personal rights.

Most notably, the character of Mister Ed is an outspoken advocate of an attitude which Gary L. Francione has described as "abolitionism" (xi). Referring to the historical movement against U.S. slavery, Francione defines "abolitionism" as a radical defense of basic personal rights for animals. If we are about to consider, as the title of Francione's book suggests, "animals as persons," we also have to promote "the interest of nonhuman animals" (148). This radical approach is similar to that of "critical anthropomorphism" (Garrard 157), which proposes that we should "align [our]selves with the views of animals that are commonplace outside science" (Garrard 158). In this context, "Ed the Emancipator" (1963; season 3, episode 24) repeatedly references the abolitionist movement of the mid-nineteenth century. Tellingly, this episode aired on March 24, 1963; that is, in the midst of the Civil Rights Movement and just five months before the "March on Washington." In the episode, Mister Ed is revealed as an avid reader of Abraham Lincoln's writings, especially of the Gettysburg address. Ed's provocative question "Does that go for horses, too?" (01:08-01:10) summarizes the main argument of the animal liberation movement, which demands a deeper understanding of nonhuman animals' needs and necessities. We almost expect Mister Ed to reiterate the famous abolitionist slogan "Am I Not a Man and a Brother?" so evident are the links between the historical abolition of slavery and the possible abolition of animal subjugation raised in the show.

The fact that Mister Ed is a horse (and not a dog or cat) is significant in this context. As Donaldson and Kymlicka explain, horses played a key role in the technological revolutions of the nineteenth and twentieth centuries. The main reason for the transition from horse power to the combustion engine was that horses were feared by their owners as a "disruptive workforce" (115; see also McShane), being potentially rebellious and unwilling to work. In this context, Mister Ed's constant refusal to work alludes to the numerous stories of zoo and circus animals that tried to escape their captivity and caused serious damage-acts the authorities later construed as unintended accidents or results of random behavior (see Donaldson Kymlicka 115-116). Mister Ed leaves no doubt that its main character's actions in the name of emancipation are intended. This sense of fundamental agency on the part of the animal protagonist imbues the show with more than just the average sitcom humor. The fact that the horse Ed is elevated to the status of a "Mister" while its owner is simply called by his first and last names underlines the impression of comical destabilization and reversal of the roles humanity has assigned to the respective species.

\section{Conclusion}

In this essay, I have argued that the CBS sitcom Mister Ed employs an aesthetics of dehierarchization, embracing subjectivities that seem closely linked to the world of the "animal Other"-the subjugated, the repressed. The show employs the fiction of "nonhuman agency" to pose fundamental questions regarding the positioning of the 
"animal subaltern" in society and the role of humans in this subjugation. The sitcom genre plays a crucial role in this politics of reversal, allowing viewers to laugh with the animal character (rather than at it). In this sense, Mister Ed participates in a carnivalesque spectacle which, by celebrating the absurd and the grotesque, embraces peripheral viewpoints and identity positions. Likewise, Mister Ed can be interpreted as a colonialized subject, a kind of "animal subaltern" (Willett 26-29) that speaks up against an oppressive system. The laughter evoked in these episodes assumes, in a postcolonialist sense, an emancipatory quality, associating us with what Donna Haraway has called "subjugated standpoints" (191-192) - those symbolic hinges within hegemonic culture that help valorize "situated knowledges" (Haraway 149-201) and generate a more complex understanding of cultural practice as a whole.

The show's title character, oscillates between various "situated knowledges," serving as a prime example of what Paul Wells has called "bestial ambivalence" (51), a radical fluctuation between oppositional notions of body, identity, gender, race, ethnicity, and species. Ed partly reflects the human mindset of his eccentric owner Wilbur Post (who is likewise portrayed as a liminal character) and partly celebrates a non-human subject position (e.g. when the horse replaces the cowboy as the true hero of the West). The show's anthropomorphism, I have argued, invites us to re-think established modes of agency and question our own perception with regard to what is possible and what is impossible. By generating "structures of feeling" (R. Williams) that connect the human and the non-human, the divide between species is imaginatively suspended. Hence, in some episodes, the horse protagonist transforms into a "Mister Id," expressing the secret yearnings of his human companion Wilbur to the viewer. "I belong with the rejected," Ed declares in "Ed the Beachcomber" (14:21) - a statement that must have found fertile ground in 1962, the heyday of what James Baldwin once described as the "New Lost Generation" (659). In view of the flourishing civil rights movement of the early sixties, Mister Ed's blatant commitment to emancipatory causes would have probably sounded revolutionary, had it not been concealed in the shape of a sitcom, that highly formulaic and often conservative television genre which emerged as a popular format during the fifties. Yet, Mister Ed subverts many of the genre's ritualistic patterns, for example, by choosing an animal as its title character and by having that protagonist converse and joke in an amiable fashion. Just a decade earlier, during the "paranoid fifties" (to use Richard Hofstadter's famous phrase), the figure of Mister Ed, being endowed with such a rebellious attitude, might have easily been ostracized as a "Mister Red."

When confronting the gaze of animals, historian John Berger has maintained, we are looking "at something that has been rendered absolutely marginal" (34; original italics). In Mister $E d$, this marginal dimension of animals is combined with a set of political messages. Continuously marked in the show as "the Other," the non-human character becomes a representative of emancipatory causes, thus mocking existing hierarchies and transgressing the established boundaries between identity positions and even species. Embellished with comical elements, the format visualizes and reverses what Derrida has termed, with regard to animal subjectivity, the "possibility of the impossible" (28), allowing the talking horse to figure as a spokesperson for a whole array of political and social issues-equal treatment of African Americans, rebellious youth, even animal rights. Constructed as a "liminal animal denizen" (Donaldson and Kymlicka 210-251), a resident of two different worlds, the character of Mister Ed rejects 
the binary assumptions of the human/non-human dichotomy, endorsing a series of fluid identity positions instead. Similar to its main character, the show Mister Ed occupies a niche within social and cultural practice, encouraging viewers to do the same and inhabit the space between "human" and "non-human," "civilized" and "wild," "assimilated" and "rebellious."

\section{BIBLIOGRAPHY}

Ahmad, Diana L. Success Depends on the Animals: Emigrants, Livestock, and Wild Animals on the Overland Trails, 1840-1869. Reno: U of Nevada P, 2016. Print.

Ahuja, Neil. "Postcolonial Critique in a Multispecies World.” PMLA 124.2 (2009): 556-563. Print.

“Anthropocentric.” Oxford Living Dictionaries. Web. 22 Nov. 2017.

“Anthropocentric.” Merriam-Webster. Web. 5 Dec. 2017.

“Anthropomorphism.” Oxford Living Dictionaries. Web. 12 Dec. 2017.

Armstrong, Philip. “The Postcolonial Animal.” Society \& Animals 10.4 (2002): 3-9. Print.

---. What Animals Mean in the Fiction of Modernity. London: Routledge, 2008. Print.

Baker, Steve. Picturing the Beast: Animals, Identity, and Representation. Urbana: U of Illinois P, 2001. Print.

Bakhtin, Mikhail. Problems of Dostoevsky's Poetics. 1929. Trans. and ed. Caryl Emerson. Minneapolis: U of Minnesota P, 1984. Print.

---. Rabelais and His World. 1965. Trans. Hélène Iswolsky. Bloomington: Indiana UP, 1984. Print.

Baldwin, James. “The New Lost Generation.” 1961. Collected Essays. New York: Library of America, 1998. 659-668. Print.

Baucom, Ian. "The Human Shore: Postcolonial Studies in an Age of Natural Science." History of the Present: A Journal of Critical History 2.1 (2012): 1-23. Print.

Berger, John. Why Look at Animals? 1980. London: Penguin, 2009. Print.

“The Blessed Event.” Mister Ed: The Complete Series. Writ. Bob O’Brien and Ben Starr. Dir. Arthur Lubin. Shout! Factory, 2014. DVD.

Burt, Jonathan. Animals in Film. London: Reaktion Books, 2002. Print.

Carroll, Noël. A Philosophy of Mass Art. Oxford: Oxford UP, 1998. Print.

Chagani, Fayaz. “Can the Postcolonial Animal Speak?” Society \& Animals 24.6 (2016): 619-637.

Print.

DeMello, Margo, Animals and Society: An Introduction to Human-Animal Studies. New York: Columbia UP, 2012. Print.

Derrida, Jacques. The Animal That Therefore I Am. New York: Fordham Univ. Press, 2008. Print. 
Donaldson, Sue, and Will Kymlicka. Zoopolis: A Political Theory of Animal Rights. Oxford: Oxford UP, 2011. Print.

Eagleton, Terry. The Ideology of the Aesthetic. Cambridge: Blackwell, 1990. Print.

“Ed Agrees to Talk." Mister Ed: The Complete Series. Writ. Lou Derman and Ben Starr. Dir. Arthur Lubin. Shout! Factory, 2014. DVD.

"Ed Discovers America." Mister Ed: The Complete Series. Writ. Lou Derman and Larry Rhine. Dir. Arthur Lubin. Shout! Factory, 2014. DVD.

“Ed Finally Talks a.k.a. George Burns Meets Mister Ed.” Mister Ed: The Complete Series. Writ. Lou Derman. Dir. Arthur Lubin. Shout! Factory, 2014. DVD.

“Ed the Beachcomber." Mister Ed: The Complete Series. Writ. Lou Derman and Robert O'Brien. Dir. Arthur Lubin. Shout! Factory, 2014. DVD.

"Ed the Desert Rat." Mister Ed: The Complete Series. Writ. Stanley Adams, Bill Davenport, and Lou Derman. Dir. Ira Stewart. Shout! Factory, 2014. DVD.

“Ed the Emancipator." Mister Ed: The Complete Series. Writ. Lou Derman and Bob O’Brien. Dir. Arthur Lubin. Shout! Factory, 2014. DVD.

"Ed the Voter." Mister Ed: The Complete Series. Writ. Lou Derman. Dir. Arthur Lubin. Shout! Factory, 2014. DVD.

"Ed Writes Dear Abby.” Mister Ed: The Complete Series. Writ. Lou Derman and Larry Rhine. Dir. Arthur Lubin. Shout! Factory, 2014. DVD.

Fanon, Frantz. The Wretched of the Earth. 1963. Trans. Richard Philcox. New York: Grove, 2004. Print.

Fisher, John A. "High Art versus Low Art." The Routledge Companion to Aesthetics. $2^{\text {nd }}$ ed. Ed. Berys Gaut and Dominic McIver Lopes. London: Routledge, 2005. 527-540. Print.

Foucault, Michel. The Order of Things: An Archaeology of the Human Species. 1970. New York: Vintage Books, 1994. Print.

---. Power/Knowledge: Selected Interviews and Other Writings, 1972-1977. Ed. Colin Gordon. New York: Pantheon, 1980. Print.

Francione, Gary L. Animals as Persons: Essays on the Abolition of Animal Exploitation. New York: Columbia UP, 2008. Print.

Fudge, Erica. Animal. London: Reaktion Books, 2002. Print.

Garrard, Greg. Ecocriticism. $2^{\text {nd }}$ ed. London: Routledge, 2012. Print.

Gramsci, Antonio. Selections from the Prison Notebooks. Ed. Quintin Hoare and Geoffrey NowellSmith. London: Lawrence and Wishart, 1971. Print.

Haraway, Donna J. Simians, Cyborgs, and Women: The Reinvention of Nature. New York: Routledge, 1991. Print.

Hintz, Harold F. Horses in the Movies. New York: A.S. Barnes \& Company, 1979. Print.

Hofstadter, Richard. "The Paranoid Style in American Politics." 1964. The Paranoid Style in American Politics. New York: Vintage Books, 2008. 3-40. Print.

Horse Feathers. Dir. Norman Z. McLeod. Cast: Groucho Marx, Harpo Marx, Zeppo Marx, Chico Marx. Paramount Pictures, 1932. 
“Horse Sense.” Writ. Robert O’Brien and Ben Starr. Dir. Arthur Lubin.

Hribal, Jason. Fear of the Animal Planet: The Hidden History of Animal Resistance. Introduction by Jeffrey St. Clair. Oakland, CA: Counter Punch Press and AK Press, 2010.

Huggan, Graham, and Helen Tiffin. Postcolonial Ecocriticism: Literature, Animals, Environment. London: Routledge, 2010. Print.

Körber, Achim. "Why Everybody Loves Flipper: The Political Economy of the U.S. Dolphin-Safe Laws.” European Journal of Political Economy 14 (1998): 475-509. Print.

Lévi-Strauss-Claude. Totemism. 1962. Trans. Rodney Needham. Boston: Beacon, 1963. Print.

McShane, Clay, and Joel A. Tarr. The Horse in the City: Living Machines in the Nineteenth Century. Baltimore, MD: Johns Hopkins UP, 2007. Print.

Mills, Brett. The Sitcom. Edinburgh: Edinburgh UP, 2009. Print.

---. Television Sitcom. London: BFI, 2005. Print.

“Mister Id.” HorsesforDiscourses. Internet Blog. 30 Apr.2014. Web. 15 Oct. 2016.

Moore, Stephen D. "Introduction: From Animal Theory to Creaturely Theology.” Divinanimality: Animal Theory, Creaturely Theology. Ed. Stephen D. Moore. New York: Fordham UP, 2014. 1-16. Print.

Mundy, John, and Glyn White. Laughing Matters: Understanding Film, Television, and Radio Comedy. Manchester: Manchester UP, 2012. Print.

Rancière, Jacques. The Politics of Aesthetics. 2000. Trans. Gabriel Rockhill. London: Bloomsbury, 2013. Print.

Salinger, J. D. The Catcher in the Rye. 1951. New York: Penguin, 1994. Print.

Shillinglaw, Ann. “Mister Ed Was a Sexist Pig." Journal of Popular Culture 30.4 (1997): 245-254.

Print.

Shusterman, Richard. "Entertainment: A Question for Aesthetics." The British Journal of Aesthetics 43.1 (2003): 289-307. Print.

Sikov, Ed. Laughing Hysterically: American Screen Comedy of the 1950s. New York: Columbia UP, 1994. Print.

Singer, Peter. Animal Liberation: Towards an End of Man's Inhumanity to Animals. 1975. New York: HarperCollins, 2009. Print.

Spiotta-DiMare, Loren. Performing Horses: Horses That Entertain. Berkeley Heights, NJ: Enslow, 2014. Print.

Spivak, Gayatri Chakravorty. "Can the Subaltern Speak?" 1988. The Norton Anthology of Theory and Criticism. $2^{\text {nd }}$ ed. Ed. Vincent B. Leitch. New York: Norton, 2010. 2114-2126. Print.

“Subaltern." Oxford Living Dictionaries. 23 Nov. 2017.

Terrace, Vincent. Television Series of the 1960s: Essential Facts and Quirky Details. Lanham, MD: Rowman \& Littlefield, 2016. Print.

Traïni, Christophe. The Animal Rights Struggle: An Essay in Historical Sociology. 2011. Trans. Richard Jemmett. Amsterdam: Amsterdam Univ. Press, 2016. Print.

Wells, Paul. The Animated Bestiary: Animals, Cartoons, and Culture. New Brunswick, NJ: Rutgers UP, 2009. Print 
Willett, Cynthia. Interspecies Ethics. New York: Columbia UP, 2014. Print.

\section{NOTES}

1. Horsin' Around is the title of a mock sitcom in the animated television series BoJack Horseman (Netflix, since 2014), which is about anthropomorphic, talking horses.

2. Similar scenes of Mister Ed using a typewriter appear in several other episodes. For example, in "The Blessed Event" (1963; season 3, episode 26), Mister Ed learns that he will become an uncle, whereupon he walks straight to the typewriter to create a list of suitable names (09:4710:00). Similarly, in "Ed Writes Dear Abby" (1964; season 5, episode 3), Ed types a letter for a newspaper column to complain about the restrictions he has to endure at home (08:57-09:02).

3. According to Oxford Living Dictionaries, "anthropomorphism" is defined as "[t]he attribution of human characteristics or behavior to a god, animal, or object" ("Anthropomorphism"). On the one hand, the character of Mister Ed seems anthropomorphized in that it displays "human attributes" and touches upon sensitivities of human society. On the other hand, the discourse of "bestial ambivalence" inscribed into Mister Ed allows for a reading that underlines Ed's "animalness" (especially with regard his status as an "animal subaltern").

4. Examples include The Adventures of Rin Tin Tin (ABC, 1954-1959) and Lassie (CBS, 1954-1971; syndication 1971-1973). Although these dog characters were designed to maintain the postwar illusions of newly discovered peace and domesticity, they also harken back to a tradition of political animal agency. For example, in the eponymous 1943 movie, the "Son of Lassie" was portrayed as a devoted freedom fighter and enemy of the Nazis. The theme of emancipation became present, once again, in the television show Fury (NBC, 1955-1960). Its title character was an untamed American Saddlebreed horse that refused to be ridden by anyone else but the orphan boy Joey, who is adopted by a rancher in the Wild West.

5. The bottlenose dolphin Flipper in the eponymous NBC series (1964-1967) politicized a whole generation of young consumers, laying the ground for the "dolphin-safe tuna" movement of the 1990s (see Körber 475-509). Other TV formats, such as Daktari (CBS, 1966-1969), directed the viewers' attention to the need to protect wildlife (see Traïni 170).

6. Mister Ed won a Golden Globe in 1963 for "Best TV Show-Comedy." Much later, the show won TV Land Awards for "Favorite Pet-Human Relationship" (2003) and "Most Heart Warming PetHuman Relationship" (2005)-a prize presented to Alan Young, the actor playing Ed's owner Wilbur Post.

7. The show's basic idea originated in a film series titled Francis the Talking Mule from the early fifties that also revolved around a likeable, wisecracking animal character conversing with its owner. Around mid-century, Americans were already familiar with comical metaphors involving horses. The 1932 pre-Code Marx Brothers comedy film Horse Feathers about a college football team made clear reference to the common expression "horse feathers" for "complete nonsense."

8. In his book The Politics of Aesthetics (2000; English translation 2004), Jacques Rancière describes "aesthetic acts" as "configurations of experience that create new modes of sense perception and induce novel forms of political subjectivity" (3). The politics of aesthetics takes its recognizable shape in "the distribution of the sensible" (7), namely the "regime of the arts in general" (9) and its "system of representation" (13).

9. The term "sitcom" (short for "situation comedy") defines a fast-paced, often serialized comedic format on television that is marked by highly formulaic patterns, including the infamous "canned laughter" suggesting appropriate moments for amusement. As John Mundy and Glyn White elaborate in Laughing Matters (2012), the situation comedy "developed out of the variety sketch adapted to the regular broadcasting radio to become the most efficient form for delivering comedy within television" (105). Following Brett Mills, the sitcom is "the result of the 
interplay between the comic impetus of all comedy and the specifics of television" (Sitcom 23). In the contemporary era, the sitcom is "the predominant comedic form in television, being the favourite television genre in the USA and the second favourite in the UK" (Mundy and White 105).

10. In his study of 1950s Hollywood cinema, Laughing Hysterically (1994), Sikov identifies the "generalized hysteria" (19) of the postwar era as the basis for the emergence of various "hysterical" screen comedies. While some featured Jerry Lewis and other comedians with a decisively vaudevillian kind of humor (18-19), others were directed by Frank Tashlin who combined an anarchic sense of humor, borrowed from the Warner Brothers' Looney Tunes series with elements of subversive humor (179-242).

11. Fisher cites Carroll's book A Philosophy of Mass Art as an example of a scholarly study in which the boundaries between high and low culture (and especially its allegedly formulaic structures) are called into question. High art, Fisher insists, can be highly formulaic, too, in its aesthetic structures and form of expression (534; see Carroll 196).

12. In Mister Ed, we also find both the "double act" and the "ensemble cast." For example, the show strongly emphasizes the relationship between Ed and his owner Wilbur (played by Alan Young). It also develops much of its humor through minor characters as well, especially Wilbur's wife (played by Connie Hines) and the Addisons, the Posts' neighbor couple (played by Larry Keating and Edna Skinner).

13. In this respect, Mister $E d$ stands in contrast to other TV shows with animal protagonists such as Lassie and Flipper, who are at the center of their respective plots but are never allowed to talk to audiences directly or narrate events from their perspectives.

14. For a discussion of Bakhtin's "theory of the carnivalesque," see Richard Shusterman's essay "Entertainment: A Question for Aesthetics" (291).

15. "[T]o speak of 'non-human agency'," Armstrong states in What Animals Mean in the Fiction of Modernity, "immediately invites the allegation of anthropomorphism" (3). However, "mobilizing a concept of animal agency need not imply 'assumptions about what specifically constitutes animal subjectivity or interiority" (3; see also Burt 31). In fact, "the allegation of anthropomorphism itself derives from an anthropocentric and ethnocentric understanding about what agency is" (Armstrong, Animals 3).

16. In The Order of Things (1970), Foucault encourages us to reconsider "what kind of impossibility [we are] faced with" when looking at the gap between social practice and representation (xv). Sometimes, the grotesque and absurd may challenge our established modes of thinking and facilitate social and political change. A critical analysis of the human/non-human dualism, Erica Fudge argues, is capable of stimulating "our own ability to think beyond ourselves, to include within the orbit of our imaginations ... those beings of other species" (22).

17. Literally speaking, Mister Ed opposes the patterns of anthropocentrism, since it revolves around the world of its horse protagonist, even creating a material setting (a bed, a typewriter, etc.) that focuses on Ed's existence as an independent character. Within this setting, Mister Ed is always a liminal character, embodying human and non-human features alike.

18. Coming from a similar angle, Ian Baucom proposes uniting the concerns of postcolonial studies with those of planetary or global studies, creating an environmentalist discourse that takes questions of imperialism into consideration (20). For a detailed discussion of "animals" as a discursive theme in ecocriticism, see Garrard (146-180).

19. The ordeal of assuming the right to vote and finding one's way through the "red tape" of bureaucracy is described in detail in this episode, reminding us of the obstacles imposed upon the African American minority in the form of the 'Jim Crow Laws' (making literacy and possession of property prerequisites for voting). Notably, the 'Jim Crow Laws,' which had dominated since the 1890s, were still in place when "Ed the Voter" aired on November 5, 1961. Seen in this light, Ed's statement from the episode's final scene, "I sure am lucky to be living in a 
democracy" (24:11-24:13), could easily be seen as ironic, since the Civil Rights Act, which ended the most outrageous elements of voting injustices, was only signed into law by President Johnson three years later.

20. Oxford Living Dictionaries defines the term "subaltern" as "[o]f lower status" ("Subaltern"). Originally used by Marxist theorist Antonio Gramsci to label the "popular mass," postcolonial scholar Gayatri Chakravorty Spivak picked up the concept of the "subaltern" in a 1988 essay, which positioned itself within the discourse of "subaltern studies" (launched by a number of Indian researchers surrounding Ranajit Guha). A combined definition of the term enables us to use "subaltern" both in a postcolonial sense (indicating the animal's "otherness" within the colonial system of human hegemony) and in the general sense (pointing to the "lower rank" of non-humans in Western societies).

21. In her essay, Spivak investigates what she calls "the persistent constitution of the Other as the Self's shadow" (2114). Within the symbolic order of constant "Othering" that characterizes the imperialist system, the subaltern is prevented from articulating its oppressed and marginalized status. Combining "subaltern studies" with thoughts developed by Foucault and Deleuze, Spivak raises the question whether "the oppressed, if given the chance ... can speak and know their conditions" (2117; original italics).

22. The irony of this episode is enhanced by the fact that Ed simultaneously transforms into a human (a western hero) and (metaphorically) into another animal, a "desert rat," as the title suggests. This doppelganger image supports Ed's ambivalent status oscillating between the world of humans and non-humans.

23. In this context, it is important to note that Mister Ed usually encourages us to laugh with its animal protagonist (who provides most of the show's jokes and witticisms). Here, the show employs an aesthetic constellation symptomatic of the American sitcom genre. "While American sitcom often invites the audience to laugh with characters, Britcom instead offers pleasure in laughing at them" (Mills qtd. in Mundy and White 113; my emphases).

24. This effect was achieved by an intense training program, during which the gelding Bamboo Harvester, who initially played the character of Mister Ed, "learned to move his lips on cue when the trainer touched its hoof" (Spiotta-DiMare 33).

25. According to Terry Lovell, "[t]he stronger the referencing to social reality, the less 'subversive' sitcoms tend to be" (qtd. in Mundy and White 106). Following Lovell's logic, Mister Ed, which creates numerous fantastic and unrealistic scenarios, must be considered subversive.

26. In the Merriam-Webster dictionary, 'anthropocentric' is defined in two ways: "1. Considering human beings as the most significant entity of the universe" and " 2 . Interpreting or regarding the world in terms of human values and experiences" ("Anthropocentric"). The sitcom Mister Ed comically discards both criteria, declaring a horse 'the most significant entity of the universe' and considering the world in terms of 'horse sense' and 'animal experience' rather than 'common sense.'

27. Spivak takes the term "subjugated knowledge" from Foucault who defines it as "a whole set of knowledges that have been disqualified as inadequate to their task or insufficiently elaborated" (Power/Knowledge 82). In her collection of essays Simians, Cyborgs, and Women: The Reinvention of Nature (1991), Donna Haraway uses the related term of "situated knowledges" (196), that is, types of knowledge which are not fixed but oscillate within the dynamics of cultural hegemony. "Subjugated standpoints"specifically, viewpoints that are not allowed to be part of hegemonic knowledge but nevertheless play a crucial role in cultural practice, since they "promise more 
adequate, sustained, objective, transforming accounts of the world" (191)-are central in this context. Both of Haraway's concepts-that of "situated knowledges" and that of "subjugated standpoints"-point to the need for a more balanced view of such identityforming processes. "A commitment to mobile positioning and to passionate detachment is dependent on the impossibility of innocent 'identity' politics and epistemologies as strategies for seeing from the standpoints of the subjugated in order to see well" (Haraway 192).

28. It is estimated that 3,000 horses died at the Battle of Gettysburg, and 8 million in World War I (Donaldson and Kymlicka 271).

29. Donaldson and Kymlicka point out that the group of "liminal animals" is often neglected by the discipline of Animal Studies. Yet, "we are not dealing with a few anomalous species here, but rather a large variety of non-domesticated species who have adapted to life amongst humans" (210).

30. Viewers encounter a similar scenario in the episode "Ed Writes Dear Abby," in which the character demands to have his own independent home, whereupon Wilbur calls him a "teenage rebel" (05:20-05:24).

\section{ABSTRACTS}

This essay discusses the aesthetics of dehierachization in one of the pioneering sitcoms in American television-the CBS-produced Mister Ed (1961-1966). Drawing on the concepts of "the animal subaltern" (Willett), "bestial ambivalence" (Wells), and "liminal animal denizenship" (Donaldson and Kymlicka), I argue that the show constructs its protagonist, a talking horse named Mister Ed, as a shapeshifting character who humorously challenges established assumptions regarding the human/animal dichotomy. Designed as a sitcom, Mister Ed employs a technique that I describe, following Bakhtin, as "carnivalesque humor." Within this aesthetic framework, the title character figures as an ambiguous and grotesque character who rejects social conventions and restrictions, oscillating between the position of a stand-in for humans and that of a liberated animal. Mister Ed playfully advocates a radical move toward alternative representations of body, identity, and species, even postulating an analogy between the African American Civil Rights Movement and the discourse of animal liberation. Following a long tradition in animal fiction, the show sets out to expose hierarchies and injustices in society by employing an animal as its chief focalizer. Conceived in this manner, Mister Ed challenges what Jacques Derrida has termed "the possibility of the impossible," namely the notion that animals can never be endowed with a sense of subjectivity. In the comedic, fictional realm of the show, the "impossible" becomes a subversive reality. Mister Ed assumes the position of a powerful subject which is endowed with "non-human agency" (Armstrong). In this sense, Mister Ed creates a scenario in which the "absolutely marginal" (Berger), indeed, returns the viewers' gaze, inviting them to share and valorize this outside perspective, if only for the duration of one twenty-five minute episode at a time. 
INDEX

Keywords: Mister Ed, carnivalesque humor, body, identity, species

\section{AUTHOR}

\section{STEFAN L. BRANDT}

Stefan L. Brandt is Professor of American Studies at the University of Graz in Austria. He has published three monographs, most recently The Culture of Corporeality: Aesthetic Experience and the Embodiment of America, 1945-1960 (2007), and five (co-)edited volumes, including Space Oddities: Difference and Identity in the American City (2018) and In-Between: Liminal Spaces in Anglo Canadian Literature (2017). In addition, he has authored numerous essays on American literature, film, and popular culture. 